Anuario Latinoamericano Ciencias Políticas y Relaciones Internacionales vol. 4, 2017

pp. 187-202

\section{Evolution of EU-Mexico relations: time for real partnership?}

DOI: 10.17951/al.2017.4.187

\section{La evolución de las relaciones UE-México: ¿tiempo para una auténtica alianza?}

\author{
Anita Oberda Monkiewicz ${ }^{1}$ \\ FACULTY OF POLITICAL SCIENCE AND INTERNATIONAL STUDIES, \\ UNIVERSITY OF WARSAW \\ POLAND \\ $\triangle$ aoberda@uw.edu.pl
}

\begin{abstract}
The evolution of the political and economic landscape in the world in recent years has made European Union "rediscover" Latin America as a partner with future potential. This interest has converged with Mexico's aspirations to activate its international policy and strengthen relations with Europe. Another aspect of this renewed interest is an attempt at balancing the weakening NAFTA and also, in a broader context, it can be included in the strategy of building alliances especially economic ones in extra-American areas. For the first time, both parties - the EU and Mexico - are showing a deep interest in intensifying mutual contacts, refreshing their formulas and giving them a new meaning. The article below is aimed at discussing the EU - Mexico relations, both contemporary and historical ones, their specificity, importance and possibilities of further development.
\end{abstract}

\section{KEYWORDS:}

Mexico, European Union, Strategic Partnership, Association Agreement, Global Agreement.

\section{RESUMEN}

La evolución del panorama político y económico del mundo en los últimos años le ha permitido a la Unión Europea "redescubrir" América Latina como un posible socio. Este interés coincide con las aspiraciones que tiene México de

1 Doctor of humanities in political science (2007). Assistant Professor at the Department of Extra-European Studies, Institute of International Relations. Holder of the Mexican Government's scholarship in 2013 (Special Program Scholarship/ High Level Program). Her interests centre around broadly understood problems of the western hemisphere, including Latin American issues, inter-American relations, development of illegal drug trade in Latin America or the position of Brazil and Mexico in international relations. 
activar la política internacional y profundizar las relaciones con Europa. Podemos considerarlas como un intento de compensar el debilitamiento del NAFTA, así como, en un contexto más amplio, inscribirlas en la estrategia de construcción de alianzas, especialmente económicas, en áreas fuera de las Américas. Por primera vez desde hace mucho tiempo las ambas partes, la UE y México, manifiestan un profundo interés en la reactivación de sus contactos mutuos, la renovación de su fórmula y una nueva orientación de estas relaciones. El presente artículo se propone comentar las relaciones entre la Unión Europea y México, tanto contemporáneas como pasadas, su especificidad, su carácter y qué oportunidades existen para su mayor desarrollo.

PALABRAS CLAVE:

México, Unión Europea, Asociación Estratégica, Acuerdo de Asociación, Acuerdo Global.

\section{As an introduction}

Due to complicated beginnings of European integration - the necessity of focusing on consolidation of cooperation of all Member States of the European Community, relations with Latin America had never been intense. The geographic distance, economic diversity of Latin American countries and the undeniable influence of the United States cast a shadow over the development of cooperation between the regions. Latin America still does not belong to priority directions of the EU's actions, however, a gradually growing interest in the development of cooperation with its individual countries can be observed. Mexico occupies a special place among them - a strategic partner, connected with the EU by means of a free trade zone and an association agreement. This article is aimed at providing an answer to the question about the importance of the Mexico-European Union relations for both partners in the context of dynamically changing political and economic situation in the world.

The main hypothesis guiding this article is that, in spite of favorable circumstances on both sides of the Atlantic and the predictions of bilateral relations going back to a genuine partnership, the potential of EU-Mexico remains unused and lacks ideas for its effective management. In 2016 negotiations on the new bilateral agreement have started which brought an opportunity for deepening the existing cooperation and extending it to new areas. Mexico is particularly interested in that and motivated for change due to perception of the European direction as an alternative to the weakening integration within the NAFTA and the counterweight to the complex transatlantic agreements negotiated nowadays by its North American partners. From the political perspective, strong relations with the EU could bring a reliable ally in the process of strengthening the international position of Mexico as well, which is one of the priorities of the current administration. 
The following article outlines the historical perspective of the relations between the European Union and Latin America, Mexico in particular, including their institutional structure, main achievements and challenges existing in their political and economic dimensions, as well as the evolution of their global surroundings. In view of this, systemic and historical methods were used in this article to analyze the development of the Mexico - European Union relations and their place in transatlantic context.

\section{European Union - Latin America: an overview}

Cooperation between the European Economic Community (EEC) and Latin America was officially launched in 1958 when the Memorandum on Relations with Latin America was signed with the purpose of establishing closer links under the principles of reciprocity, mutual benefit and respect for the rights of all parties involved. While the document was not binding, it nonetheless started a process of deepening the cooperation with Latin American countries, including talks on abolishing tariffs on certain goods in the mutual trade.

In the early 1960s, the European Community established a Contact Group with Latin American countries, which was the first forum for the exchange of opinions of the two parties in the years 1961-1963. The institutionalization of political cooperation started in the 1970s, largely due to the activity of the Special Commission for Latin American Cooperation (Comisión Especial de Coordinación Latinoamericana, CECLA) and the Buenos Aires Declaration in 1970 with the proposal of forming a commission for interregional dialogue. As a result, an interregional conference was held in 1971 in Brussels, starting the so-called "Brussels dialogue" between European Communities representatives and the Group of Latin American Ambassadors (Grupo de las Embajadores Latinoamericanos, GRULA) in the following years.

The decade of the 1970s also brought the first agreements with Latin American countries, i.e. with Argentina (1971), Uruguay and Brazil (1973) and Mexico (1975). The institutional aspect of these relations was strengthened due to the European Commission's first program of cooperation with the countries of Asia and Latin America (ALA) adopted in 1976, under which financial assistance was provided to Latin America.

However, only the 1980s brought an impulse for actual development of relations with Latin American countries, mainly due to the so-called San José dialogue concerning the peaceful termination of conflicts in Central America and the EU accession of Spain and Portugal in 1986 - natural advocates of closer contacts with the Latin American region. As a result, in 1987, New Guidelines for the Relations with Latin America and further (second generation) agreements were signed with Central American countries as well as the Andean Pact.

The end of the Cold War converged with the dynamic changes in the political and economic landscape in both regions which promoted the strengthening
Evolution of EU-Mexico relations: time for real partnership?

Anita Oberda Monkiewicz 
of existing relations. Democratization processes in many Latin American countries, liberalization of economies in accordance with recommendations of the Washington Consensus and the birth of New Regionalism created good grounds for intensification of contacts. At the same time, the adoption of the Maastricht Treaty and the establishment of the European Union created a completely new value of such contacts. From the European perspective, another factor in favour of the "rediscovery" of Latin America was growing competition on the part of dynamically developing "Asian tigers" and the deepening processes of economic liberalization and political democratization on the Old Continent. Over the subsequent years, The Community developed preference for contacts with existing integration organizations and individual subregions. In 1999, a strategic partnership was announced in Rio de Janeiro (the so-called Rio Process), with a view to consolidating space for political dialogue and interregional cooperation, and it was gradually completed with the introduced free trade area. Europe tried to distance itself from a purely commercial approach and to promote instead a regulatory role incorporating three dimensions: political, through multilevel dialogues - the EU-LAC Summits amongst many others; economic, including trade and investment; and development cooperation, incorporating social policies (Gardini, Ayuso 2015: 11). The interregional strategy functioned essentially until the EU-LAC Summit in Madrid in 2010. It was meant to lead to the establishment of a high-level political dialogue and a network of partnership agreements with individual LA countries, including free trade agreements (FTAs) that would go beyond the traditional model of North-South economic relations. At present, relations with Latin America are being developed at various levels (interregional, subregional and bilateral). As a result of multiple dimensions of cooperation, the relations between the European Union and Latin America are more a polyphony than a dialogue and thus require modernization.

In a sense, a response to need for a change is a gradual shift of the EU stance towards bilateral relations tailored to specific expectations and conditions. Starting from the 21st century, the EU will create a network of Association Agreements with LAC countries, covering the economic (FTAs, investment) and political cooperation, as well as Strategic Partnerships, based mostly on political dialogue and sectoral cooperation. For the EU, Mexico is one of priority countries in the Latin American region, which can be confirmed by the fact that it is the only country that has been both associated with the EU (since 2000) and has also been its strategic partner (since 2008).

\section{Mexico in the European Agenda}

In recent years, Mexico has been implementing an ambitious strategy of increasing its presence and importance internationally as one of the most important emerging countries and the 14th largest economy. It has a well- 
developed network of trade agreements all over the world and is a major player in international fora like the United Nations, G20, APEC (Asia-Pacific Economic Cooperation), and OECD (Organisation for Economic Cooperation and Development), among others. One of Mexico's biggest assets is also its geographic location: a natural, strategic bridge between North America and Latin America, as well as straddling the Atlantic and the Pacific Oceans, which gives Mexico a truly competitive advantage that has not yet reached its full potential.

Mexico was also one of the first Latin American countries which initiated official relations with the integrating Europe. The European Union and Mexico signed an agreement on establishing diplomatic relations in 1960 and the first Mexican diplomatic representative at the EEC was Primo Villa Michel. However, mutual relations became slightly more intense in the 1970s. An attempt at establishing closer relations with Europe was made by Luis Echeverra's government (1970-1976) in response to the crisis of the model of economic development based on substituting imports with industrialization and the growing awareness of economic dependence on the United States (Castro Espinosa 2003: 895). As a result, a Framework Agreement for Cooperation between Mexico and the European Economic Community was signed in 1975. It was drawn mostly on the initiative of Germany and Italy which treated this agreement as a kind of counterbalance for intensive cooperation between Great Britain and its colonies. Mexico was granted the "highest privilege clause" and several bilateral projects were launched which concerned, amongst other things, cooperation in the private sector, science and technology and support for the power sector. However, this agreement did not lead to actual closeness between entities; it did not facilitate equal access of Mexican goods to the European market.

The 1980s were the time when a breakthrough occurred in the development of relations between the European Union and Latin America. Gradual opening of the Mexican economy, deepening European integration and accession of Spain and Portugal to EU - natural advocates of closer relations with Latin America - all contributed to the intensification of the bilateral agenda. Positive experience was also derived from cooperation in solving Central American problems within the so-called San José process, as a result of which progressing institutionalization of the political dialogue and economic cooperation was observed, which is confirmed by over 40 agreements signed between Mexico and the European Community (Castro Espinosa 2003: 896). The intensification of cooperation largely resulted from the fact that Mexico was one of the first Latin American countries to start the process of liberalization of its economy which increased the attractiveness of the Mexican market as well as by redefinition of the foreign policy at the time, which after a third-world period began to aspire to approximation to the so-called first world. As a result, Mexico was accepted to the General Agreement on Tariffs and Trade (GATT) in 1986, APEC (Asia-Pacific Economic Cooperation) in 1993 and also to
Evolution of EU-Mexico relations: time for real partnership?

Anita Oberda Monkiewicz 
OECD (Organization for Economic Cooperation and Development) in 1994. This contributed to a change in the perception of Mexico in Europe. The EU began to perceive it - in accordance with Mexico's strategy at the time - as a medium-developed country in relations with which promotion of trade and investments should predominate instead of developmental aid (de Vega Armijo, Riguzzi, Ruano 2011: 420).

The beginning of the next decade and the accompanying changes on the political and economic map of the Old Continent made it necessary to redefine European priorities and to focus on internal matters. According to Álvaro Castro Espinosa, this inertia on the part of the European Community resulted in Mexico focusing on processes of regional integration and on development of cooperation with the United States. Despite this, in 1991, another framework agreement for cooperation was signed which was a thirdgeneration agreement including a broad scope of cooperation with emphasis on economic cooperation and creating huge potential for dynamization of mutual relations, although it was not preferential (Czarnacki 2007: 191).

In the mid-1990s, the EU's attitude towards Mexico became much keener. This mostly resulted from fear of marginalization of European interests in North America in view of intense integration processes in the region and the fact that the North American Free Trade Agreement (NAFTA) started bringing positive results. This considerably deteriorated the terms of trade in relations between Mexico and the EU and had a negative effect on the conditions of operation of European enterprises on the Mexican market. Spain and Portugal became eager enthusiasts of closer contacts between the European Union and Latin America which promoted the "Europeanization" of EU relations with the Latin American region.

Mexico, aspiring to the status of the voice of the entire region not only actively joined the mechanism of biregional summits initiated in 1999 (Ruano 2008: 312), but it also focused on intensification of bilateral relations with the EU. President Ernesto Zedillo (1994-2000), who was a proponent of increased cooperation with Europe at the time, strived to start negotiations on a new agreement which would take into account the establishment of a free trade zone, amongst other things. This idea received positive response, especially in countries with significant investments in Mexico, such as Spain and Great Britain which were afraid of losing the market to the USA and Canada as a result of refusal to sign the agreement. However, the majority of European countries had a sceptical attitude, resulting from both political conditions (violations of human rights and failure to comply with democratic principles in Mexico) and economical ones (fears of negative consequences of the potential free trade zone on the EU's Common Agricultural Policy). Ultimately, the growing attractiveness of the Mexican market and intensive development of NAFTA were the deciding factors which led to the commencement of negotiations (Sanahuja 2013: 175). The four-year period of negotiations was not easy. There was no consensus in Europe about the final shape of the 
agreement. France and Germany opted for an agreement with preferential access to markets instead of creating a direct free trade zone, which, on the other hand, was supported by Great Britain and Spain (Castro Espinosa 2003: 899). The so-called democratic clause also turned out to be controversial as it made possible for the Community to suspend cooperation if violations of democratic principles or human rights were found. Mexico, facing numerous internal problems, tried to weaken its importance, treating it, in a way, as an attempt to undermine its independence. Finally, after long negotiations, the clause was included in the agreement, which to a substantial extent marked the beginning of new quality in relations between Mexico and the European Union.

In 1997, Mexico was the first Latin American country to sign the Economic Partnership, Political Coordination and Cooperation Agreement with the EU. This "Global Agreement", which took effect in 2000, covers political dialogue, trade (Tratado de Libre Comercio, TLCUEM) and cooperation. This agreement is supplemented with agreements with individual European countries concerning the protection of investments, issues of double taxation as well as agreements which specify the principles of cooperation in the area of science and technology and human rights. Political dialogue takes place in the form of cyclic meetings of representatives at various levels during which specific bilateral issues are discussed. The structure of cooperation also includes annual interparliamentary meetings and dialogue between civil societies. One of its achievements has been the establishment of an EU-Mexico free trade area - a major boost to bilateral trade and investment.

The Global Agreement made it possible to deepen the relations between Mexico and the European Union despite unfavourable international conditions and internal problems. In 2008, these relations becameeven moreinstitutionalized when the Strategic Association Agreement was signed. Such agreements are signed by the EU with countries with similar regional or global potential and usually focus on the development of political dialogue which takes the form of regular consultations on various levels. At present, apart from Mexico, EU has such agreements with the USA, Canada, Russia, China, India, Japan, RSA, South Korea and Brazil. Reasons which led to the decision to offer this form of cooperation to Mexico include, amongst other things, its membership in the OECD and its perception as "bridge" between Latin America and the United States (Huacuja Acevedo 2010: 51). The strategic partnership was approved in 2008 and an action plan was adopted two years later (it included fourteen multilateral actions, two regional ones and eleven bilateral ones).

As political dialogue was one of pillars of the so-called Global Agreement which entered into force in 2000, the Strategic Association focused on enhancing the existing dialogue and establishing the relations with Mexico in the most institutionalized form among all regional partners. Also, new subject areas were included in the dialogue, such as environmental protection and cooperation in climate change (in connection with the approaching COP16),
Evolution of EU-Mexico relations: time for real partnership?

Anita Oberda Monkiewicz 
and the reform of the international financial system (within G20) - at the bilateral level - was also added to the issues of human security rights. Multilateral issues included international financial crisis, food security, non-proliferation of weapons of mass destruction, illicit trade in arms, UN reform, international security, organized crime, fight against corruption, migrations, developmental and humanitarian aid, terrorism, drugs and human security. Regional issues, in turn, covered the promotion of interregional cooperation and trilateral cooperation. Trade relations, environmental protection, sustainable development, security, human rights, education and culture, science and technology, regional development, statistics, public health and nuclear security were listed among bilateral challenges.

The association agreement between Mexico and the EU opened a new chapter in their mutual relations. The EU's protectionist barriers were eliminated and Mexico opened even more to European investments. Aa a result of the agreement, an opportunity for new quality in relations between the EU and Mexico appeared, however, it was also met with some criticism, mostly concerning the lack of expected effects, which would correspond to its political importance, and accurate guidelines regarding its implementation (Review of the association agreement: 4).

Despite this, President Vicente Fox (2000-2006) not only broadened the scope of the agenda of bilateral relations but also strived after the implementation of the strategy for increasing Mexico's presence and role internationally. At the same time, Spain which held the presidency of the EU in 2002, gave support to establishing Mexico as a key partner in development of interregional relations. The growing importance of Mexico in Latin America also allowed it to act as the voice of the entire region during summit meetings and to accept investments and trade from the Old Continent (Ruano 2008: 300-301). After a short period of benign neglect of the European direction during Felipe Calderón's administration (2006-2012), this strategy has been to a large extent implemented by Enrique Peña Nieto (since 2012), who has based his policy of increasing Mexico's global importance on good relations with Europe and Asia-Pacific.

\section{Structure of political cooperation}

Political cooperation between Mexico and the European Union takes place in a parallel manner on several levels. Mexico cooperates with the EU within Asociación Estratégica Bi-Regional Unión Europea-América Latina y el Caribe (ALCUE), which involves meetings of Heads of States and Prime Ministers of both regions on summits, while a particularly significant example of cooperation is direct high-level political dialogue in the form of EU-Mexico summits, which are held every two years, and meetings of the Joint Council of Ministers. Parliamentary dialogue is being developed together with the bilateral dimension in which Mexico focuses on several countries which 
traditionally include Spain, Germany, Great Britain and France as well as Italy, Sweden and the Netherlands (Ruano 2012: 32).

Summits of Heads of States and Governments are the highest level of political dialogue. Since 2002, meetings have been held every two years at the same time as EU-LA summits. The talks mostly concern main global problems, deepening cooperation through modernization of the association agreement and establishing positions at the international level. They are complemented by the Joint Council - the second level of political dialogue, including representatives of the European Commission, European Council as well as appropriate ministers of the Mexican government and also the Joint Committee consisting of representatives of the Joint Council which prepares meetings and deals with ongoing issues. The Joint Committee addresses issues of deepening political and economic cooperation, human rights, civil society as well as specific issues, such as facilitation of European investments in Mexico or adaptation of concluded agreements to the process of EU extension.

In 2015, the 7th EU-Mexico Summit was held during which leaders agreed to take action to update the Global Agreement, to renew political dialogue, cooperation and the economic partnership. They also stressed the importance of reinforcing the Strategic Partnership as well as the convergence in positions in multiple issues of the international agenda, such as: climate change and environment, the post-2015 sustainable development agenda, security and peace-keeping operations, the world drug problem and the fight against transnational organized crime, migration and humanitarian aid. Their talks also focused on the possibilities of expanding bilateral cooperation in research and development, especially in renewable energy and on tools to facilitate mobility and academic cooperation between Mexico and the EU.

Additionally, the EU and Mexico have established an inter-parliamentary relationship in the framework of the Joint Parliamentary Committee EU Mexico, which gathers twice a year. The Joint Parliamentary Committee is a forum for exchanging opinions between parliamentarians of both parties. Its main objective is the control of the internal situation in terms of compliance with the principles of democracy and human rights. The JPC also deals with challenges which both Mexico and the EU are facing, including security issues, millennium goals, climate change, migration, etc. The multitude of subjects undertaken by the JPC shows its activity and involvement on the one hand, however, it prevents deeper discussion, on the other hand.

The European External Action Service, in co-ordination with the Mexican Government and with the collaboration of the European Economic and Social Committee, established an EU-Mexico Civil Society Forum in order to promote the participation of civil society in the relations between the two parties. The aim of this forum is to encourage dialogue to further enrich the relations between Mexico and the European Union in all three pillars of the global agreement: political dialogue, cooperation and trade.
Evolution of EU-Mexico relations: time for real partnership?

Anita Oberda Monkiewicz 
In political matters, the relations between Mexico and the European Union are positive. Mexico is treated, alongside Brazil, as a priority country in Latin America, it also has the most institutionalized structure of cooperation. The current cooperation is aimed at establishing partnership based on shared values, which translates, amongst other things, into more intensive cooperation in international organizations, especially as regards global issues such as climate change, sustainable development, international peace and security, democracy and human rights, global economic governance. At the multilateral level, the cooperation is equally positive, especially in the area of climate change, which was confirmed by joint preparations for the COP16 summit in Cancún in 2010.

However, political relations are not free from certain challenges. Controversial issues include, amongst other things, the question of compliance with human rights and militarization of the war on drugs in Mexico which causes escalation of violence, which made the European Parliament to adopt appropriate resolutions (in 2007, 2010 and 2014). War on organized crime waged by the Calderón administration also deteriorated the perception of Mexico in the EU. These problems cast a shadow on bilateral relations in France (the so-called Cassez case) and led to the cancellation of the Year of Mexico in 2011 (Ruano 2012: 35). At the same time, the EU treats human rights as an important element of bilateral political cooperation and supports Mexico, amongst other things, in enhancing democratization processes. In the years 2002-2004, it made Mexico one of three priority countries within the European Initiative on Democracy and Human Rights (EIDHR) (Dominguez 2015: 75). In 2006, the EU also sent a mission of observers to the Mexican elections for the first time. It also supports democratic transformations in this country and reforms aimed at enhancing the rule of law.

Bilateral cooperation also includes cooperation in education and implementation of developmental projects. In the years 1999-2012, the European Investment Bank implemented eight projects in Mexico, especially related to industrialization and the power sector for the amount of EUR 411,5 million (Dominguez 2015: 75). The main direction of the EU's involvement in Mexico is supporting the state in increasing the level of sustainable development and aiming at alleviation of social asymmetries. In the years 2007-2013, the EU earmarked EUR 40 million for Mexico within the framework of developmental aid focusing on three main areas: social cohesion and dialogue (55\%), sustainable economy and competitiveness (25\%), education and culture (20\%). Although until 2014 Mexico had not been eligible for bilateral cooperation, the European Union is still financing activities in Mexico through thematic and regional programmes in the areas of Human Rights, environment or gender equality (Dominguez 2015: 75). In 2016, for instance, in the framework of the bilateral cooperation program "Social Cohesion Laboratory II," the European Union, granted EURO 2,4 million to eight projects managed by the Civil Society Organizations that seek to promote social cohesion in Mexico in the fields of human rights, social prevention of violence and crime, justice, health and social protection, good governance and employment. 


\section{Economic relations}

The main mechanism which regulates trade relations between Mexico and the European Union is the Global Agreement. It established a free trade zone which invigorated economic relations between entities, thus increasing not only the bilateral trade but also serving as an effective catalyst of the inflow of foreign investment to Mexico - a key element which makes it possible to reduce the economic dependence of this country on the USA.

The EU is Mexico's second biggest export market after the USA, and Mexico is the third largest source of imports after the United States and China. The EU's key imports from Mexico are mineral products, machinery and electric equipment, transport equipment and optic photo precision instruments. Key EU exports to Mexico include machinery and electric equipment, transport equipment, chemical products, and mineral products. In 2015, the trade between the EU and Mexico amounted to USD 62,1 million with a positive balance for the European Union (25,2 million). Export to the EU amounted to USD 18,4 million, which ranked Mexico as 17th EU's partner with share in UE trade of $1,1 \%$. At the same time, EU exports to the Mexican market amounted to USD 43,7 million, which gave it the 15th place among EU export partners with a $1,9 \%$ share in the whole EU trade. What is important, Mexico currently enjoys trade preferences with the EU under the Generalised Scheme of Preferences.

\begin{tabular}{ccccc}
\hline Year & Export & Import & Total & Balance \\
\hline 2009 & $11.683,7$ & $27.321,5$ & $39.005,0$ & $-15.637,8$ \\
\hline 2010 & $14.479,8$ & $32.622,8$ & $47.103,0$ & $-18.143,0$ \\
\hline 2011 & $19.170,6$ & $37.773,9$ & $56.945,0$ & $-18.603,3$ \\
\hline 2012 & $22.093,7$ & $40.961,4$ & $63.055,0$ & $-18.867,6$ \\
\hline 2013 & 19.799 .3 & $43.142,9$ & $62.942,0$ & $-23.343,6$ \\
\hline 2014 & $20.425,0$ & $44.555,3$ & $64.980,0$ & $-24.130,3$ \\
\hline 2015 & $18.440,2$ & $43.722,6$ & $62.163,0$ & $-25.282,4$ \\
\hline
\end{tabular}

Source: Balanza Comercial de México año previo de los TLCs. Vs 2015, Secretaría de Economía, Subsecretaría de Comercio exterior, http://www.economia.gob.mx/files/comunidad_negocios/comercio_exterior/informacion_estadistica/industrial_2015.pdf, accessed on: 23.05.2016.

In terms of services, EU imports from Mexico are dominated by travel, sea transport, air transport and construction services. EU export services to Mexico consist mainly of travel, sea transport, air transport and computer and information services. The bilateral stock as well as the flow of investment between the EU and Mexico is significant, however, a growing asymmetry
Evolution of EU-Mexico relations: time for real partnership?

Anita Oberda Monkiewicz

Table 1.

Trade turnover between Mexico and the EU (in millions USD) 
Artículos y ensayos

Table 2.

EU-Mexico "trade in services" statistics (in billions of Euro) to Europe's advantage can be observed. In 2014, the EU Foreign Direct Investment in Mexico was EUR 119,2 billion, while Mexican investment in the European Union amounted to approximately EUR 28,3 billion.

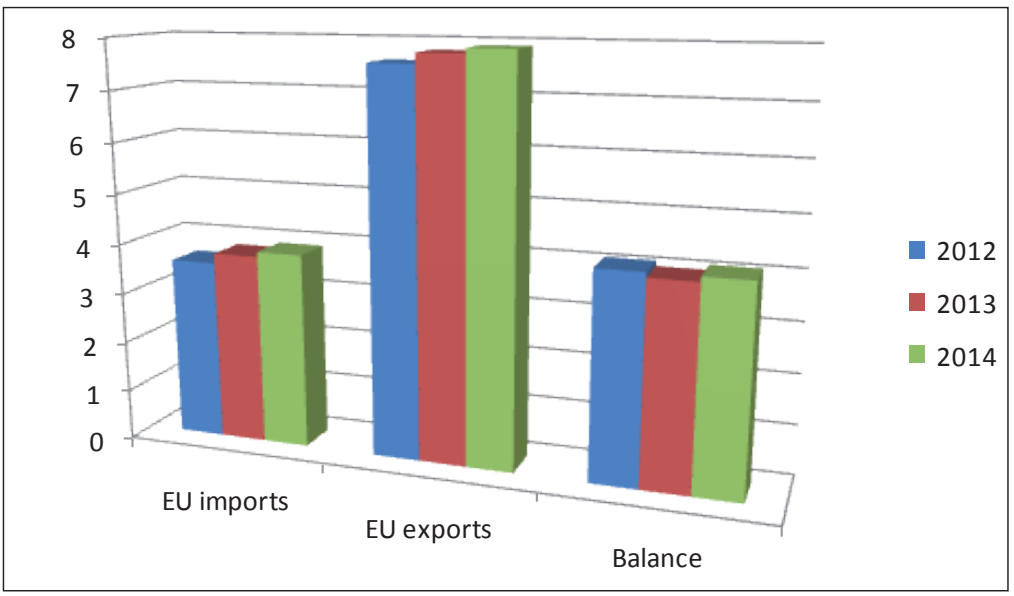

Source: European Commission, Trade, http://ec.europa.eu/trade/policy/countries-andregions/countries/mexico, accessed on: 24.05.2016.

Mexico's main objective as regards the economic relations with the EU is diversification of the market and trade contacts, especially in the context of NAFTA membership. It is true that TLCUEM made it possible to triple the trade volume between the partners but it did not significantly increase the share of the trade with Mexico in the entire EU trade. A similar situation concerns investments; an increase in their size was observed but no increase in their share. The negative balance still exists in trade relations for Mexico but we do observe a positive balance in investments. Even though TLCUEM is an agreement which contains a second and third generation clause, certain barriers to the development of trade with the EU can still be observed - Lorena Ruano lists, amongst other things, insufficient infrastructure, unfamiliarity with the European market, protectionist agricultural rules and complicated EU standards in many areas. At the same time, after 2009, a decrease in the demand for Mexican products can be observed in the EU market. On the European side, customs regulations and a lack of compatibility between the rules on the governmental and local governmental levels (Ruano 2012: 33). As a result, both parties are gradually becoming aware that, especially in the context of the economic crisis, it is necessary to introduce a new, deeper formula for bilateral economic relations and extend the existing Global Agreement.

The current trade agreement is mainly focused on goods, yet it imposes various restrictions. Considering that $60 \%$ of Mexico's GDP comes from services, a chapter dedicated to the service sector should be included in the upcoming negotiations. It is also highly advisable to include conflict resolution mechanisms 
such as investor-state dispute settlement (ISDS) rules and mediation. This would reinforce a modern approach to justice that grants access to all players, taking of course into account sovereignty, regulatory issues and other sensitivities. The new treaty should provide a reliable framework, with clear and transparent rules for a comprehensive liberalization process of trade and investment that creates new jobs and opportunities for both Mexico and the EU. The new treaty might contribute to fuller use of the economic potential of bilateral relations, something that has not been fully exercised so far.

\section{Global conditions}

The main objective of the Global Agreement, which has been in force since 2000 , is to increase bilateral trade and investment flows to contribute to the economic growth of both partners. In 2010, the EU launched Europe 2020, an ambitious growth strategy to foster a smart, sustainable and inclusive economy as an answer to the economic crisis. As part of that, the EU aims at building upon and enlarge its strategic partnerships and consolidate its role among the key players in the world; this includes reviewing the trade agreements already in place with major partners. In North America, examples of this strategy include the conclusion of the Comprehensive Economic and Trade Agreement (CETA) with Canada, negotiations with the USA concerning TTIP (Transatlantic Trade and Investment Partnership), and the initiative to upgrade the current trade agreement with Mexico.

The economic reforms which have been recently implemented in Mexico, including greater openness to foreign investment and global cooperation, are perceived in a positive manner in Europe - as a successful example of modernization of the economy. Mexico recovered relatively quickly after the last economic crisis and, thanks to the so-called "Mexican Moment," major reforms were achieved in strategic sectors including education, energy and telecommunications. These reforms were driven by the "new government" image that Mexico projected to the world - a country with a solid structure where political consensus was finally achieved for the first time since 2000. Despite Mexico's success in the international sphere, there are still internal challenges that need to be resolved with comprehensive reforms that foment credibility and good governance practice. The EU's concerns can be seen, amongst other things, in resolutions and recommendations encouraging the Mexican government to enhance the rule of law and to implement an action plan to tackle insecurity and corruption, which are major concerns for foreign investors.

Nonetheless, from the economic point of view, Mexico is one of the more and more important players around the world, not just amongst the emerging markets. Its value chain integration is a key factor encouraging investment by European companies. In recent years, with a highly import-dependent
Evolution of EU-Mexico relations: time for real partnership?

Anita Oberda Monkiewicz 
energy sector, manufacturing in Europe is becoming more expensive and less competitive. Mexico has consolidated its position as a production and exporting powerhouse not only to the United States, but also to Central and South America. On the other hand, Mexico has the potential to become a powerful provider of renewable energies, proven by the vitality of its manufacturing industries and export-friendly infrastructure. Furthermore, Mexico claims to be the cheapest labour force in the world, with production costs $20 \%$ lower than in China. All this makes Mexico interesting to investors. The EU, however, needs to strike a careful balance between trade benefits of delocalization and the risk of social dumping.

The economic crisis in Europe greatly revalued relations between the European Union and Latin America. It particularly affected economies of countries opting for closer relations with Latin American countries (such as Spain and Portugal) shifting the point of reference towards new partners. At the same time, intensive regional integration processes are also observed in Latin America which do not only lead to erosion of the principles of the Washington Consensus but, on the contrary, increase disparities between the liberal and protectionist models of development. According to José Briceño Ruiz, the main line of division in Latin America currently runs along three main axes: open integration (Pacific Alliance), revisionist approach (Mercosur) and anti-systemic approach (ALBA). Each of them corresponds to a different economic model based on various approaches to economic development and various strategies of becoming included in the global economy. Cintia Quiliconi distinguishes two distinct blocs in Latin America: countries oriented on cooperation with the Pacific area and promoting neoliberal principles (e.g. the Pacific Alliance) and the ones that support the active role of the state in the economy. The competing blocs represent two completely opposing visions of development which the author defines as "competitive bilateralism" versus "open regionalism". We also observe a change in the international power structure - the United States, as one of the most important points of reference in international relations in the western hemisphere is gradually losing the monopolist position to the new entities, including ones that implement the strategy of China's economic expansion. In this context, Eu revised its existing Latin America policy from bi-regional to bilateral with focus on Strategic Alliances with individual regional partners. Due to the fact that, generally speaking, position of Mexico in the European Union's strategy stemmed from the organization's little interest in Latin America - the adoption of the bilateral strategy by the EU allows to upgrade efficiently the existing relations.

One can get the impression that the best prospects for the development of relations with the EU exist now from Mexico's perspective as well. On the one hand, this corresponds to the promoted strategy of more active political activity globally and, on the other hand, from the economic point of view, both partners are looking for alternative markets and diversified economic partners. In the face of the loss of interest of other member states in developing NAFTA and, 
through it, new directions for European (CETA/T-TIP) and Asian cooperation (Trans-Pacific Partnership, TPP), Mexico decided to take care of its position in the aforementioned areas on its own. Renegotiating the agreement with Europe - which started in June 2016 - is, in a way, a response to the lack of progress in developing the North American Free Trade Area and it prevents a potential marginalization of Mexico. According to the strategy of increasing the international role of Mexico promoted by the Peña Nieto administration, its driving force is to be the simultaneous strengthening of economic relations within NAFTA, with the EU and Asia and Pacific. In a sense, it is also aimed at balancing the Asian direction of economic expansion which is developed within the framework of the Pacific Alliance and the Trans-Pacific Partnership.

Deepening relations with the European Union is based mostly on the assumption of the growing importance of Mexico as an emergent power and a strong economic position of the EU. On the one hand, Mexico's rapprochement with the EU is seen as a way to support its global ambitions by presenting both partners as strategic, political allies in key areas such as climate changes, energy, education, technology, innovation, digital agenda, culture, etc. This ambitious global strategy fits the dynamically changing political and economic landscape of the world where emerging economies, such as Mexico, are gaining momentum. On the other hand, negotiations on enlarging the Global Agreement are justified mainly by the economy. TTIP which is being negotiated by the US is perceived as a threat to the position of Mexican goods in the US market, especially in the context of the gradual exhaustion of the model of economic integration proposed by NAFTA and the search for diversification for the member states through economic contacts in Europe and Asia. Potential trade diversion caused by TTIP could have strong negative impact on Mexico, particularly in sectors that are deeply integrated with the US. Mexico is worried that TTIP could weaken NAFTA and make it redundant, by shrinking its exports to the US, as well as reducing its competitiveness and access to the US market for strategic goods. In this context, efforts to renew the Global Agreement are perceived as a way to compensate for this and boost Mexican trade with the EU, including increased access to the European market for the agricultural goods as well as services and investments. You can say that, in some way, Mexico is forced to rediscover the European direction for its economic and political strategy because if it stays passive, it could lose not only potential benefits on the European market but also on the American one.

After many years of at least lukewarm relations both partners are truly interested in developing their cooperation - both on bilateral and global level. Still, you have to take into account that neither Mexico, nor EU are priority partners and their relations, especially economic, remain largely asymmetric and may do so in the future. However, Mexico depends more on the EU than vice versa - especially for economic reasons which could be a good motivation for intensifying mutual cooperation. The new agreement can help to exploit the full potential of existing relationships and establish stable links in new areas such as energy or
Evolution of EU-Mexico relations: time for real partnership?

Anita Oberda Monkiewicz 
climate change. It could be also a great possibility to move finally beyond declaration and find a stable ground to build efficient partnership in future.

\section{References}

Briceño Ruiz J. (2014), Del regionalismo abierto al regionalismo poshegemónico en América Latina, en: Política Internacional e Integración Regional Comparada en América Latina, W. Soto Acosta (ed.), FLACSO, San José.

Castro Espinosa Á. (2003), Tan lejos de Europa y tan cerca de los Estados Unidos. Orígenes, negociación y perspectivas del acuerdo político y comercial entre México y la Unión Europea, "Foro Internacional", vol. 43, no 4 (174), pp. 893-916.

Czarnacki M. (2007), Stosunki polityczne i gospodarcze Unii Europejskiej z Ameryka Łacińska i Karaibami, in: Unia Europejska. Integracja, konkurencyjność, rozwój, K. A. Kłosiński (ed.), Wydawnictwo KUL, Lublin.

Domínguez R. (2015), EU Foreign Policy toward Latin America, Palgrave Macmillan UK.

Europejski Komitet Ekonomiczno-Społeczny (2015), Przegląd układu o stowarzyszeniu między UE a Meksykiem, Bruksela.

Gardini G. L., Ayuso A. (2015), EU-Latin America and Caribbean Inter-regional relations: complexity and change, "Atlantic Future Working Paper", no 24, http://www.atlanticfuture. eu/files/1530-LA-EU.pdf, accessed on: 04.08.2016.

Huacuja Acevedo L. A. (2010), XI Reunión de la Comisión Parlamentaria Mixta México Unión Europea, Cuaderno de Trabajo, México.

Malamud, A., Gardini G. L. (2012), Has Regionalism Peaked? The Latin American Quagmire and its Lessons, "International Spectator", vol. 47, no 1, pp. 116-133.

Pi-Suñer A., Riguzzi P., Ruano L. (eds.) (2011), Historia de las relaciones internacionales de México, 1821-2010, vol. 5, Europa, Secretaría de Relaciones Exteriores, México.

Quiliconi C. (2013), Modelos competitivos de integración en el hemisferio occidental: ¿liderazgo competitivo o negación mutual?, "Revista CIDOB d'Afers Internacionals", no 102103 , pp. $148-150$.

Ruano L. (2008), De la exaltación al tedio: las relaciones entre México y la Unión Europea durante el sexenio del presidente Vicente Fox, 2000-2006, "Foro Internacional", vol. XLVIII, no 1-2, pp. 297-329.

Ruano L. (2012), Relaciones México-Unión Europea: tendencias actuales y perspectivas, in: La política exterior de México 2012-2018. Diagnóstico y propuestas, J. A. Schiavon, R. Velazquex Flores (eds.), Asociación Mexicana de Estudios Internacionales, CIDE A. C., México D.F.

Ruano L. (2013), Inercia institucional en un ambiente difícil: las relaciones de México con Europa durante la administración de Felipe Calderón, 2006-2012, "Foro Internacional", vol. LIII, no 3-4, pp. 619-644.

Sanahuja J. A. (2013), Unia Europejska i Ameryka Łacińska. Prawidłowości i dylematy stosunków międzyregionalnych $w$ dobie globalizacji, in: Ameryka Łacińska XXI wieku. Nowe oblicza, nowe struktury, nowe tożsamości, A. Dembicz, A. Elbanowski (eds.), CESLA, Warszawa. 